of labor artels that also worked for the Military Department. The author pays special attention to the complex relations of cooperatives with the purchasing commissioners and the Zemstvo.

Keywords: agricultural cooperation, military supplies, World War I, agriculture, Middle Volga Region

УДК 340 [(47)+(51)] (091)

КУРАС Татьяна Леонидовна - кандидат исторических наук, доцент кафедры судебного права Юридического института Иркутского государственного университета (664003, Россия, г.Иркутск,ул. K. Маркса, 1; tanya_kuras@mail.ru)

КУРАС Софья Леонидовна - кандидат исторических наук, доцент кафедры таможенного дела и правоведения Иркутского государственного университета путей сообщения (664074, Россия,

г. Иркутск, ул. Чернышевского, 15; kuras@list.ru)

\title{
ОСВЕЩЕНИЕ ДЕЯТЕЛЬНОСТИ СУДЕБНЫХ ПАЛАТ РОССИЙСКОЙ ИМПЕРИИ И ОРГАНОВ ТЮРЕМНОГО ВЕДОМСТВА НА СТРАНИЦАХ «ЖУРНАЛА МИНИСТЕРСТВА ЮСТИЦИИ»
}

\begin{abstract}
Аннотация. В статье исследуется «Журнал Министерства юстиции» как источник изучения судебных органов и органов тюремного ведомства Российской империи второй половины XIX - начала ХХ в. Он сыграл значимую роль в подготовке и реализации судебной реформы на территории страны, размещая, в частности, законодательство, приказы по ведомству Министерства юстиции, материалы судебной практики, научные статьи. Журнал отражал политический курс и отношение самодержавия к реформе судебного и тюремного ведомств.
\end{abstract}

Ключевые слова: Журнал Министерства юстиции, суд, судебная палата, тюрьма, тюремное ведомство

$\mathrm{B}$ настоящее время продолжается реформирование судебных и иных правоохранительных органов. В дореволюционной Российской империи большое внимание уделялось идеологическому обоснованию проводимой политики. Современные средства массовой информации также активно помогают государству, информируя общественность об изменениях в судоустройстве, судопроизводстве и в пенитенциарной системе.

Периодические издания дореволюционной России отражали политический курс и отношение правительства к проводимой реформе судебного и тюремного ведомств. Их значение для современных исследователей весьма высоко, они являются важнейшими источниками изучения судебной системы и тюремного наказания [Курас С. 2012a: 134].

Одним из самых информационно насыщенных правовых периодических изданий дореволюционной России стал «Журнал министерства юстиции». Он начал выходить в 1859 г. Причинами его создания послужило то, что в преддверии судебной реформы проводился большой объем подготовительных работ, которые выявили острую потребность в научно-практическом издании. Оно было призвано обеспечить общение высшей власти с подчиненными органами, обсуждение законопроектов учеными и практикующими юристами, информировать население страны о проводимых работах [Маматов 2010: 102].

«Журнал Министерства юстиции» состоял из следующих разделов.

I. Часть официальная, состоявшая из трех отделов: 
1) высочайшие повеления:

a) высочайшие именные указы и повеления по предметам, относящимся к судебному ведомству и управлению министерства юстиции;

б) высочайше утвержденные мнения Государственного совета и положения комитетов министров Кавказского и Сибирского по гражданским делам;

2) правительственные распоряжения:

a) по Сенату;

б) по Министерству юстиции (распоряжения по правительственной части, извлечения из годовых отчетов, статистические сведения о судебных делах);

3) личный состав Министерства юстиции:

а) перемены в личном составе должностных лиц Сената, Министерства юстиции и судов;

б) награды, отпуска и исключения из списков.

II. Часть неофициальная, также состоявшая из трех отделов:

1) обозрения отечественного и зарубежного законодательства (материалы исследований ученых и практикующих юристов);

2) судебная практика:

a) решения по гражданским делам;

б) приговоры по уголовным делам;

в) судебная практика иностранных судов.

3. Рассуждения по законодательству и библиография (обозрение юридических книг и журналов).

«Журнал Министерства юстиции» в качестве специального органа министерства просуществовал 11 лет; в 1870 г. его издание было прекращено. Причиной стало то, что Министерство юстиции рассматривало данное издание как временное, до появления частных изданий. Однако такие издания не смогли функционировать без субсидий, а потребность в специальном органе судебного ведомства постоянно росла ${ }^{1}$. Отсутствие особого печатного органа судебного ведомства стало осложнять деятельность Министерства юстиции, особенно к 1894 г., когда на него была возложена работа по пересмотру судебных порядков. В этот период обмен мнениями с учеными и практикующими юристами был крайне необходим.

В связи с этим министерство признало необходимым возобновить с 1894 г. издание журнала. На расходы по изданию журнала из государственного казначейства было выделено 5 тыс. руб. в год, начиная с 1895 г. Печатание издания было запланировано на бесплатной основе в Сенатской типографии. С указанного времени журнал без перерыва выходил до 1917 г. Издание должно было стать отражением направлений деятельности министерства. В силу этого было признано необходимым получение обязательного экземпляра для всех судов.

Серьезное внимание «Журнал Министерства юстиции» уделял освещению вопросов обоснования необходимости проведения судебной реформы. Авторы на страницах издания активно критиковали дореформенную судебную систему. Позиция ученых и практикующих юристов о необходимости проведения реформы была единой [Василевский 1863: 77-78]. Также в журнале аргументировалось, почему реформу нельзя было провести сразу во всей стране - для этого потребовались бы очень большие материальные средства. Кроме того, в России не было необходимого числа лиц, отвечавших требованиям закона, предъявлявшимся к судьям. Помимо этого, предполагалось, что

\footnotetext{
1 От редакции. - Журнал Министерства юстиции. 1894. № 1. С. 1-5.
} 
при поэтапном проведении реформы можно будет учесть опыт и недоработки, имевшие место в начале ${ }^{1}$.

Журнал постоянно освещал подготовку и проведение судебной реформы, процесс создания судебных палат и судов их округов на территории страны. Началом проведения реформы стало открытие Санкт-Петербургской и Московской судебных палат и судов их округов. 19 марта 1866 г. было подписано и размещено в журнале высочайшее повеление «О порядке введения Судебных уставов 20 ноября 1864 г. в Санкт-Петербургской и Московской губерниях» 2 . В журнале размещались и приказы о назначении должностных лиц судебного ведомства. Журнал подробно освещал процедуру торжественного открытия первых судов. Открытие Санкт-Петербургской судебной палаты и судов ее округа было произведено 17 апреля 1866 г. ${ }^{3}$ После этого 23 апреля министр юстиции произвел открытие Московской палаты и судов ее округа 4 .

В последующем журнал продолжил освещать вопросы проведения судебной реформы на территории страны и открытия новых судов. Так, в одном из номеров журнала было описано открытие Иркутской палаты и судов ее округа 2 июля 1897 г., приведена речь министра юстиции ${ }^{5}$.

Отметим, что Министерство юстиции придавало особую значимость созданию новых судов на окраинных территориях империи и проведению там политики государства в области судоустройства и судопроизводства. В связи с этим министр юстиции посещал, к примеру, Варшавскую судебную палату и суды ее округа четыре раза за период с 1876 по 1894 г. Эти поездки освещались на страницах «Журнала Министерства юстиции», призванного идеологически поддерживать деятельность самодержавия.

Судебная реформа постепенно реализовывалась на всей территории страны. К началу XX в. по всей России действовали новые суды, было создано 14 судебных округов во главе с судебными палатами. При открытии судов возникала потребность их укомплектования лицами, соответствующими требованиям закона. Для этого власть переводила опытных членов судебных палат, созданных в начале судебной реформы, в новые суды. К примеру, при проведении в конце XIX в. реформы в Сибири в новые суды было назначено около половины судей из Европейской России. В «Журнале Министерства юстиции» публиковались все приказы о перемещениях членов судебных палат. Их анализ за период с 1896 по 1917 г. позволил сделать вывод, что в составе Московской палаты за это время в должностях членов палаты, прокуроров и их товарищей работало более 100 чел., в Санкт-Петербургской палате - более 2007. С 1897 по 1917 г. в Иркутской палате работали 41 член суда и 19 прокуроров и их товарищей [Курас Т. 2002: 76-80]. Перемещения осложняли деятельность судов, но

\footnotetext{
1 Сведения о ходе работ по введению в действие судебной реформы. - Журнал Министерства юстищии. 1865. № 10. С. 51.

2 О порядке введения Судебных Уставов 20 ноября 1864 г. в Санкт-Петербургской и Московской губерниях: Высочайшее повеление от 19 марта 1866 г. - Журнал Министерства юстиции. 1866. № 1. С. 63-64.

3 Там же. С. 275-276.

4 Открытие новых судебных установлений в Санкт-Петербурге и Москве. - Журнал Министерства юстиции. 1866. № 4. С. 203-208.

5 Открытие иркутских судебной палаты и окружного суда. - Журнал Министерства юстиции. 1897. № 7. С. 121-134, 125-126.

6 Хроника. Министр юстиции в Варшаве. - Журнал Министерства юстищии. 1894. № 1. C. $185-190$.

7 Назначение и перемещение членов судебных палат в Российской империи (на примере Московской палаты). - Вестник Восточно-Сибирского государственного технологического университета. 2011. № 2(33). С. 192.
} 
были объективно необходимы. В то же время по результатам изучения приказов выявлено достаточно большое число судей, длительное время служивших в одном месте, что являлось важным фактором обеспечения стабильности работы судов.

То, что «Журнал Министерства юстиции» создавался как ведомственный журнал и был призван проводить политику самодержавия, несомненно, накладывало отпечаток на размещавшиеся в нем материалы. В то время как иные юридические издания стремились показать существующие проблемы, данный журнал, наоборот, старался представить все в положительном ключе, обходя «острые углы». Так, с 1880-х гг. появилась серьезная проблема, связанная с взаимоотношениями судов и прокуратуры. Через нее Министерство юстиции негласно собирало сведения о судьях, в т.ч. для решения вопроса об их назначениях, что создало фактическую зависимость судей от прокуроров [Градовский 1883]. В дореволюционной юридической печати акцентировалось внимание на поведении прокуроров, несовместимом с положением суда. Так, подчеркивались частые случаи воздействия прокуратуры на суд, проявление неуважения к нему1. Давалась отрицательная оценка ситуации, при которой происходило «уродливое сближение» прокурорского надзора с административными властями и их влияние на суд ${ }^{2}$. Главенствующее положение прокуратуры во взаимоотношениях с судом фактически поощрялось Министерством юстиции, т.к. на прокуратуру в политических процессах возлагалась обязанность обеспечения вынесения жестких приговоров. Однако в публичных выступлениях, размещавшихся на страницах «Журнала Министерства юстиции», министр подчеркивал, что процесс основан на состязательности и равноправии сторон; суд должен давать преимущество защите над обвинением; задачей прокуратуры является поддержание законности; прокурор должен «ограждать невинного от неправильного осуждения»; целью прокурора является установление истины $^{3}$. При размещении в журнале результатов работы комиссии для пересмотра законоположений по судебной части вопросы взаимоотношений суда и прокуратуры также освещались в положительном ключе. Отмечалось, что судьи и чины прокурорского надзора «содействуют правильному отправлению правосудия»; отношения между чинами судебного ведомства «не оставляют желать лучшего» [Городыский 1901: 8, 12-13].

«Журнал Министерства юстиции» среди прочего уделял большое внимание судебной практике по отдельным категориям гражданских и уголовных дел [Курас С. 2012б: 146]. Вхождению судебной практики в качестве источника права в российскую правовую систему в пореформенный период способствовал Правительствующий сенат. Он являлся высшим кассационным судом страны, давал разъяснения, подлежащие опубликованию в «Журнале Министерства юстиции». Тем самым решения Сената становились доступными для изучения судьями, учеными, широкой юридической общественностью. Отметим, что формированию единообразной судебной практики способствовали также судебные палаты. С учетом позиций Сената они анализировали судебную практику для применения нижестоящими судами, обеспечивая единообразие практики на территории судебных округов [Курас Т. 2018: 122]. К примеру, необходимость обобщения судебной практики Иркутского судебного округа обосновывалась его значительной территорией, отсутствием постоянных путей

1 Сообщение. - Судебная газета. 1883. № 17 (24 апр.). С. 3-4.

2 Наш западный край - накануне судебной реформы. - Судебная газета. 1883. № 20 (15 мая). С. 2.

3 Хроника. Отказ прокурора на суде от обвинения подсудимого (статья 740 уст. угол. суд.). - Журнал министерства юстииии. 1916. № 4. С. 180. 
сообщения. Для облегчения работы судов округа председатель гражданского департамента палаты И.В. Францессон подготовил 219 тезисов по вопросам толкования права и судебного управления [Францессон 1906а; 1906б].

В некоторых номерах журнала размещались научные статьи, посвященные вопросам исполнения наказания. Так, один из авторов провел сравнительную характеристику судебной и тюремной частей в России и за рубежом, подробно исследовал европейский и американский опыт. Автор констатирует, что тогдашнее состояние тюрем не отвечало цели исправления преступника. Делается вывод, что труд является лучшим средством воздействия на заключенных, подготовки их к свободе, обучения ремеслу, которое дает им заработок в тюрьме и возможность зарабатывать после выхода оттуда. Кроме того, труд покрывает часть огромных расходов на содержание мест заключения, поэтому он должен быть производительным [Гогель 1897: 160, 166].

«Журнал Министерства юстиции» рассматривал различные организационные вопросы, связанные с функционированием органов тюремного ведомства. Так, в 1897 г. освещалась процедура вхождения Главного тюремного управления (ГТУ) в состав Министерства юстиции. На страницах издания размещались сведения о комиссии, которая была создана для правового регулирования работы ГТУ и работала весь 1896 г. Комиссия составила проект временных правил об устройстве центральной части тюремного ведомства и ее местных частей. Наибольшее внимание в ее работе было уделено деятельности ведомства на местах. Было решено создать «губернские и областные тюремные управления, в составе начальников сих управлений с канцелярией при них и присутствий по тюремным делам». Эти управления должны были заниматься вопросами общей деятельности тюремного учреждения. Судьбой отдельных заключенных или сотрудников ведомства должна была заниматься коллегия из представителей администрации, суда, прокуратуры и Общества попечительного о тюрьмах. 23 декабря 1896 г. труды комиссии были представлены министру юстиции 1 .

Таким образом, «Журнал Министерства юстиции» стал одним из самых информационно насыщенных правовых периодических изданий пореформенной России. Он сыграл значимую роль в подготовке и реализации судебной реформы на территории страны, размещая на своих страницах, в частности, новое законодательство, приказы по ведомству Министерства юстиции, материалы судебной практики, научные статьи. В отличие от других изданий, он отражал политический курс и отношение самодержавия к реформе судебного и тюремного ведомств. В настоящее время журнал является важнейшим источником изучения судебной системы и тюремных органов.

\section{Список литературы}

Василевский А. 1863. Отзывы русских газет и журналов о судебной реформе. Журнал Министерства юстиции. № 4. С. 49-80.

Гогель С.К. 1897. Арестантский труд в русских и иностранных тюрьмах. Журнал Министерства юстищии. № 2. С. 159-220.

Городыский Я.К. 1901. Наши суды и судебные порядки по данным ревизии 1895 года. - Журнал Министерства юстиции. № 2. С. 1-43.

Градовский Г. 1883. Еще о прокуратуре. - Судебная газета. № 19. С. 4-5.

Курас С.Л. 2012а. Проблемы преступления и наказания на страницах литера-

1 Работы особой комиссии для составления законодательных предположений об устройстве тюремной части в ведомстве Министерства юстиции. - Журнал Министерства юстиции. 1897. № 1. С. 42. 
турного обозрения «Журнала министерства юстиции». - Власть. № 4. С. $134-$ 136.

Курас С.Л. 2012б. Судебная практика как источник изучения преступности и ссылки в Сибирь. - Власть. № 1. С. 144-147.

Курас Т.Л. 2002. История Иркутской судебной палаты (1897-февраль 1917г.): дис. ... К.И.н. Иркутск: Иркутский государственный университет. 330 с.

Курас Т.Л. 2018. Судебная практика как источник права в пореформенной России второй половины XIX - начала XX в. - Власть. Т. 26. № 3. С. 118-123.

Маматов М.В. 2010. О ведомственных СМИ в царской прокуратуре. -Законы России: опыт, анализ, практика. № 10. С. 102-107.

Францессон И.В. 1906а. Судебная практика Иркутской судебной палаты по гражданскому департаменту и общему собранию департаментов за время со второй половины 1897 года до конца первой половины 1900 года. - Журнал Министерства юстиции. № 5. С. 242-272.

Францессон И.В. 1906б. Судебная практика Иркутской судебной палаты по гражданскому департаменту и общему собранию департаментов за время со второй половины 1897 года до конца первой половины 1900 года. - Журнал Министерства юстиции. № 8. С. 186-239.

KURAS Tatyana Leonidovna, Cand.Sci. (Hist.), Associate Professor of the Chair of Justice, Law Institute, Irkutsk State University(1 K. Marksa St, Irkutsk, Russia,664003; tanya_kuras@mail.ru)

KURAS Sofia Leonidovna, Cand.Sci. (Hist.), Associate Professor of the Chair of Customs Affairs and Jurisprudence, Irkutsk State Transport University (15 Chernyshevskogo St, Irkutsk, Russia, 664074; kuras@list.ru)

\section{COVERAGE OF THE ACTIVITIES OF THE JUDICIAL CHAMBERS OF THE RUSSIAN EMPIRE AND THE BODIES OF THE PRISON OFFICE ON THE PAGES OF THE JOURNAL OF THE MINISTRY OF JUSTICE}

\footnotetext{
Abstract. The article examines the Journal of the Ministry of Justice as a source for the study of the judicial authorities and the bodies of the prison department of the Russian empire in the second half of the $19^{\text {th }}$ and early $20^{\text {th }}$ century. This journal played a significant role in the preparation and implementation of judicial reform in the country, placing, in particular, legislation, orders of the Ministry of Justice, materials of judicial practice, scientific articles. The magazine reflected the political course and attitude of the autocracy towards the reform of the judicial and prison departments.

Keywords: Journal of the Ministry of Justice, court, court chamber, prison, prison department
} 